\title{
Macro mineral requirements by grazing zebu bovines ${ }^{1}$
}

\author{
Eduardo Henrique Bevitori Kling de Moraes $^{2}$, Mário Fonseca Paulino ${ }^{3}$, Kamila Andreatta \\ Kling de Moraes ${ }^{4}$, Sebastião de Campos Valadares Filho ${ }^{3}$, Isis Lazzarini ${ }^{5}$, João Paulo Ismério \\ dos Santos Monnerat ${ }^{5}$, Victor Rezende Moreira Couto ${ }^{5}$, Marcos Gonçalves de Souza ${ }^{6}$
}

\author{
${ }^{1}$ Partially funded by CNPq and FAPEMIG. \\ 2 ICAA/Zootecnia/UFMT, Sinop-MT, 78557-267. Researcher from INCT-Ciência Animal. \\ ${ }^{3}$ DZO-UFV, Viçosa-MG, 36570-000. Scholar from CNPq. \\ ${ }^{4}$ ICAA/Zootecnia/CUS/UFMT, Sinop-MT, 78557-267. \\ ${ }^{5}$ Programa de doutorado, DZO-UFV, 36570-000. Scholar from CNPq. \\ 6 Programa de doutorado, UNESP, Jaboticabal-SP, 14884-900.
}

\begin{abstract}
The objective of this study was to determine requirements of calcium (Ca), phosphorus (P), magnesium $(\mathrm{Mg})$, potassium $(\mathrm{K})$ and sodium $(\mathrm{Na})$ for grazing zebu bovines. The experiment area was composed of Brachiaria decumbens paddocks. Twenty-seven non-castrated animals, with initial live weight of $311.0 \mathrm{~kg}$ and at an average age of 14 months were used. Three animals were slaughtered, after adaptation period, so they were used as control for estimates of empty body weight and initial body composition of animals in the experiment. Out of the 24 remaining animals, four were sent to the maintenance group with restrict grazing time to limit energy intake close to the maintenance level. The other 20 animals were distributed in four treatments: mineral mixture, self-control intake and three-times-a-week-offer frequency (offered on Mondays, Wednesdays and Fridays) and daily. Concentrations of all studied macro elements in empty body and empty body gain decreased as live weight increased. The ratios obtained for $\mathrm{g} \mathrm{Ca} / 100 \mathrm{~g}$ of retained protein and g P/100 g of retained protein were 9.18 and 4.72, respectively. Total dietary requirement of calcium was lower than the one recommended by NRC (2000), but $\mathrm{P}$ requirement was very close to that.
\end{abstract}

Key Words: macro minerals, pasture, requirement, zebu cattle

\section{Introduction}

In Brazil, beef cattle feeding is strongly supported by tropical forage, especially under pasture, which must supply essential nutrients (energy, protein, mineral and vitamins) for animal production.

As for mineral supply, it is known that tropical grasses usually present low contents and do not meet the requirements of grazing cattle. Mineral deficiency is common in grazing bovine in Brazil (Tokarnia et al., 2000), and phosphorus (P) deficiency is the most critical one (Moraes, 2001). Thus, mineral supply has been utilized both by mineral supplementation or inclusion in energy-protein supplements.

However, for proper mineral mixture formulation, one needs to know the nutritional requirement of the supplemented category. It is observed that one obstacle to meet functional requirement of the animal is the knowledge of amount required per each mineral. Therefore, requirement values recommended by ARC (1980), AFRC (1991) and NRC (2000) were used. Nevertheless, it is completely permissible to infer that because of the differences in breeds, production levels, feeds and weather conditions, most of the time, the requirements recommended by those committees are not applicable for Brazilian rearing conditions, especially for grazing cattle.

On the other hand, most information on Brazilian requirements is from experiments with animals reared in confinement. Although pastures are the basis of Brazilian cattle raising, the number of studies involving macro mineral requirements by grazing beef cattle is very limited.

Therefore, the objective of this research is to estimate net and dietary requirements of calcium, phosphorus, magnesium, potassium and sodium for zebu bovine reared in the supplement-pasture system in the rainy and rainy-dry transition periods.

\section{Material and Methods}

The experiment was carried out in Setor de Bovinocultura de Corte at Universidade Federal de Viçosa from March to June, 2007. Twenty-seven non-castrated beef bovine at 14 months of age and $311.0 \mathrm{~kg}$ were used.

At the beginning of the experiment, three animals which served as reference in body composition study were slaughtered. The 24 remaining animals were distributed 
among the following treatments: maintenance(MT), mineral mixture (MM), self-control (SF) and three-times-a-weekfrequency (Mondays, Wednesdays and Fridays $-3 \times$ ) and every day $(7 \times)$ (Table 1$)$.

On the days when animals were supplemented, animals from the $3 \times$ treatment were fed $1.283 \mathrm{~kg}$ and animals from the $7 \times$ treatment were fed $0.550 \mathrm{~kg}$, and after seven days, each animal was fed the same supplement amount (3.850 kg/animal/week). The complete random experimental design was used.

Four animals were sent to the MT treatment, subjected to a restrict pasture with the objective to meet maintenance requirements. They were released at 6:00 a.m. and locked in a shed at 10:00 a.m., totaling four hours of grazing to keep feed intake at a level slightly above maintenance requirement (Fontes et al., 2005). Experimental period lasted 84 days; animals were weighed at the beginning of the experiment and then every 28 days.

The experimental area was composed of five 2.0-ha paddocks, formed with Brachiaria decumbens Stapf. provided with drinkers and open troughs. With the objective to minimize possible influence of variation on DM availability in the pasture, animals remained in each paddock for seven days and after this period a rotation was started between paddocks (the same treatment applied to the animals was maintained).

Sampling of forage consumed by the animals was carried out through manual grazing simulation. Digestibility trial

Table 1 - Supplement percentage composition, based on natural matter

\begin{tabular}{lccc}
\hline Ingredient & \multicolumn{3}{c}{ Suplemment } \\
\cline { 2 - 4 } & $\begin{array}{c}\text { Mineral } \\
\text { mixture }\end{array}$ & $\begin{array}{c}\text { Self- } \\
\text { control }\end{array}$ & Frequency \\
\hline Mineral mixture & 100 & 10 & 10 \\
Urea:ammonium sulfate $(9: 1)$ & - & 10 & - \\
Soybean meal & - & - & 50 \\
Corn gluten meal (21\% CP) & - & - & 40 \\
Wheat meal & - & 80 & - \\
\hline CP - crude protein. & & &
\end{tabular}

was carried out at the beginning of the second weighing of the animals after 46 experimental days. Fecal excretion was estimated by using chromic oxide and calculated based on the ratio between the marker quantity and its concentration in the feces (Burns et al., 1994). The marker was applied in a single daily dose ( $15 \mathrm{~g} /$ animal), packed in paper cartridges and directly placed in the esophagus of the animals by using an applicator for nine consecutive days. After six days of application, feces of the animals were collected on the seventh (8:00 a.m.), eighth (12:00 p.m.) and ninth (4 p.m.) days.

Estimates of individual voluntary intake were obtained by using indigestible acid detergent fiber (ADFi) as a marker and the following equation: $\mathrm{DMI}=\{[(\mathrm{FE} \times \mathrm{MCF})-$ MS], MCFO + SDMI, in which DMI = dry matter intake, $\mathrm{FE}=$ fecal excretion (kg/day); $\mathrm{MCF}=$ marker concentration in the feces $(\mathrm{kg} / \mathrm{kg}) ; \mathrm{MS}=$ marker present in the supplement (kg/day); $\mathrm{MCFO}=$ marker concentration in the forage $(\mathrm{kg} / \mathrm{kg})$ and SDMI = supplement dry mater intake ( $\mathrm{kg} /$ day $)$.

Pasture and fecal samples were pre-dried in a forced ventilation oven at approximately $60{ }^{\circ} \mathrm{C}$ for 72 hours and ground in a knife mill with $1.0 \mathrm{~mm}$ mesh sieve. Chemical composition (Table 2) of the supplements and pasture were determined according to techniques described by Silva \& Queiroz (2002), except for NDF and ADF determinations, which followed the methods of Van Soest \& Robertson (1985) and Mertens (2002), respectively.

Animal slaughter was performed by brain concussion, followed by jugular vein section, after a 16-hour fasting. Slaughter was done in a staggered manner with the animals from treatments $3 \mathrm{X}, 7 \mathrm{X}$, self-control and mineral mixture slaughtered after 98, 103, 105 and 110 days of supplementation, respectively. At each slaughter, one animal from the maintenance group was randomly chosen to be slaughtered together with the other animals.

During slaughter, samples of blood, diaphragm, liver, heart, kidneys, spleen, lung, tongue, rumen-reticle, omasum, abomasum, small intestine, large intestine, mesentery,

Table 2 - Supplement and pasture chemical composition

\begin{tabular}{|c|c|c|c|c|}
\hline \multirow[t]{2}{*}{ Item (\% DM) } & \multicolumn{3}{|c|}{ Supplement } & \multirow[t]{2}{*}{ Pasture } \\
\hline & Mineral mixture & Self-control & Frequency & \\
\hline Dry matter & 98.75 & 89.57 & 89.97 & 24.73 \\
\hline Organic matter & - & 74.10 & 83.78 & 89.95 \\
\hline Crude protein & - & 39.84 & 33.66 & 8.91 \\
\hline Ether extract & - & 2.42 & 1.79 & 1.21 \\
\hline Total carbohydrates & - & 31.84 & 48.33 & 79.83 \\
\hline Neutral detergent fiber & - & 34.62 & 23.50 & 75.12 \\
\hline Non-fibrous carbohydrates & - & 13.32 & 22.81 & 4.71 \\
\hline Acid detergent fiber & - & 11.50 & 11.24 & 44.15 \\
\hline Lignin & - & 2.69 & 1.62 & 4.48 \\
\hline
\end{tabular}


internal fat, esophagus, trachea and reproductive system, leather, tail, head and members were collected and weighed. Guts and organs were washed and their weights were added to the weights of the other parts of the body (carcass, leather, head, members and blood), obtaining the empty body weight (EBW) of each animal.

Blood samples were collected immediately after jugular vein section of the animals, placed in glass containers and left in a forced ventilation oven at $60^{\circ} \mathrm{C}$ for 72 hours.

Carcass of the animals was divided into two halves, which were weighed, and then cooled in cold chamber at $-5^{\circ} \mathrm{C}$, for around 20 hours. After that, the half carcass was taken from the cold chamber and completely dissected, then muscle, adipose and bone tissue were separated and weighed.

After grinding of organs, guts, fat and muscles and section of bones (carcass, head and members), tail and leather, samples were placed in glass $(500 \mathrm{~mL})$, taken to the oven at $105^{\circ} \mathrm{C}$ for 72 to 96 hours for determination of fat dry matter (FDM). Next, each sample was washed in petroleum ether, from which pre-defatted dry matter (PDDM) was obtained. Samples were ground in a ball mill for further determination of total nitrogen (TN) and EE, according to Silva \& Queiroz (2002). Fat removed in the pre-defattening was calculated by the difference between FDM and PDDM, whose result was added to the one obtained for residual EE in PDDM, for determination of total fat content. From the knowledge of protein content and EE in PDDM and sample weight submitted to pre-defattening, respective contents in natural matter were determined. The relationship obtained between EBW and BW of the control animals was used for estimation of initial EBW of the animals which remained in feeding. In each treatment, two animals were randomly chosen to represent it, and from each animal, samples of head and fore and hind limbs were taken for physical separation of muscles, fat, bones and leather.

Body contents of mineral macro elements in the EBW were determined as function of percentage concentration of them in the organs, guts, leather, blood, tail, limbs and carcass separated constituents (fat, muscles and bones).
Contents of mineral macro elements (Ca, P, Mg, K and $\mathrm{Na}$ ) in the body of supplemented, non-supplemented animals and for all treatments in group, were estimated by using logarithm regression equation of body content of $\mathrm{Ca}, \mathrm{P}, \mathrm{Mg}$, $\mathrm{K}$ and $\mathrm{Na}$ in function of EBW logarithm, according to ARC (1980). Equations were built by adding the values related to control animal, for supplemented and non-supplemented animals.

By deriving prediction equation of the mineral body content in function of EBW logarithm, net requirements of $\mathrm{Ca}, \mathrm{P}, \mathrm{Mg}, \mathrm{K}$ and $\mathrm{Na}$, per kg of gain of EBW were obtained and the fat content was obtained by kg of EBWG, from the following equation: $Y^{\prime}=b \cdot 10^{a} \cdot X^{b-1}$ in which, $\mathrm{Y}^{\prime}=$ net requirements of $\mathrm{Ca}, \mathrm{P}, \mathrm{Mg}, \mathrm{K}$ and $\mathrm{Na}$; $\mathrm{a}$ and $\mathrm{b}=$ intercept and regression coefficient, respectively of equation of net requirements of $\mathrm{Ca}, \mathrm{P}, \mathrm{Mg}, \mathrm{K}$ and $\mathrm{Na}$; X = EBW $(\mathrm{kg})$.

To estimate maintenance requirements of each mineral macro element, and add them to gain requirements, so to obtain total dietary requirements, recommendations of ARC (1980) and NRC (2000) were fitted for endogenous losses of $\mathrm{Ca}, \mathrm{P}, \mathrm{Mg}, \mathrm{K}$ and $\mathrm{Na}$ and bioavailability of those elements in the feeds, according to ARC (1980) and NRC (2000) (Table 3).

For conversion of BW into EBW within the weight range included in this study, the correlation between EBW and BW of the supplemented animals was calculated. For conversion of EBW gain requirements into requirements for BW gain, the factor obtained from experimental data was used.

The results were statistically interpreted through analysis of variance. Comparisons between regression equations of evaluated parameters for each treatment were carried out according to methodology recommended by Regazzi (1996) to test identity of the models.

\section{Results and Discussion}

The relationship obtained to estimate EBW from BW of the animals in this study was: $\mathrm{EBW}=\mathrm{BW} * 0.8877$. Such value is found close to the one recommended by NRC (2000) of 0.8910 and the values of 0.8975 observed by Silva et al.

Table 3 - Daily total endogen losses and bioavailability of Ca, P, Mg, Na and K in the feeds

\begin{tabular}{lcc}
\hline Element & Endogenous loss & Bioavailability (\%) \\
\hline Calcium & $15.4 \mathrm{mg} / \mathrm{kg} \mathrm{BW}^{1}$ & $50.0^{1}$ \\
Phosphorus & $16.0 \mathrm{mg} / \mathrm{kg} \mathrm{BW}^{1}$ & $68.0^{1}$ \\
Magnesium & $3.0 \mathrm{mg} / \mathrm{kg} \mathrm{BW}^{1}$ & $17.0^{2}$ \\
Potassium & Fecal $-2.6 \mathrm{~g} / \mathrm{kg} \mathrm{consumed} \mathrm{DM}{ }^{2,3}$ & \\
& Urinary $-{ }^{2} 7.5 \mathrm{mg} / \mathrm{kg} \mathrm{BW}{ }^{2}$ Salivary $-0.7 \mathrm{~g} / 100 \mathrm{~kg} \mathrm{BW}$ & $100.0^{2}$ \\
Sodium & ${ }^{2}$ Through the skin $-1.1 \mathrm{~g} / \mathrm{day}^{2}$ & $91.0^{2}$ \\
\hline
\end{tabular}

${ }^{1}$ NRC (2000); ${ }^{2}$ ARC (1980); ${ }^{3}$ DM intake observed in this study (2.20\% BW). 
(2002a), obtained from confined Nellore animals. On the other hand, Fregadolli (2005) observed the relationship between EBW and BW of 0.8575 and 0.8746 , respectively, for grazing Nellore calves.

Factor 0.9013 was used, obtained from the experimental data, for conversion of requirement for EBW gain (EBWG) in requirements for live weight gain (LWG), i.e., the requirements supplied in function of empty body weight gain have to be multiplied by 0.9013 to find the requirements in function of live weight gain. Paulino et al. (2004) found the relationship between EBWG and LBW of 0.900, close to the one presented in this study. NRC (2000) used the relationship 0.956 between EBWG and LBW.

Only one equation (joint equation) was used to estimate macro mineral body content inasmuch as the identity test among the models (Table 4), applied to regression equations of the logarithm of macro mineral body contents in function of EBW logarithm, showed no differences among treatments.

As body weight (BW) of the animals increased, it was observed that body content of $\mathrm{Ca}, \mathrm{P}, \mathrm{Mg}, \mathrm{K}$ and $\mathrm{Na}$, per kg of EBW reduced (Table 5). Similarly, net requirement of each mineral decreased as BW of the animals increased.

At birth, the skeleton represents approximately $23.0 \%$ of EBW and as the animal reaches maturity, these values drop to only 1.0\% (Robelin, 1986). On the other hand, as BW increases, fat deposition is sharpened.

Table 4 - Parameters of regression equations of logarithm content (kg) of $\mathrm{Ca}, \mathrm{P}, \mathrm{Mg}, \mathrm{K}$ and $\mathrm{Na}$ in the empty body, in function of EBW $(\mathrm{kg})$ of grazing Zebu cattle

\begin{tabular}{|c|c|c|c|}
\hline \multirow[t]{2}{*}{ Item } & \multicolumn{2}{|c|}{ Parameter } & \multirow[t]{2}{*}{$\mathrm{r}^{2}$} \\
\hline & Intercept (a) & Coefficient (b) & \\
\hline & \multicolumn{2}{|c|}{$\mathrm{Ca}$} & \\
\hline Non-supplemented & -1.2352 & 0.7975 & 0.95 \\
\hline Supplemented & -1.1236 & 0.7450 & 0.86 \\
\hline \multirow[t]{2}{*}{ Joint } & -1.1359 & 0.7519 & 0.86 \\
\hline & \multicolumn{2}{|c|}{$\mathrm{P}$} & \\
\hline Non-suplemented & -1.0440 & 0.6204 & 0.93 \\
\hline Supplemented & -1.1255 & 0.6008 & 0.88 \\
\hline \multirow[t]{2}{*}{ Joint } & -1.0955 & 0.6473 & 0.86 \\
\hline & \multicolumn{2}{|c|}{ Mg } & \\
\hline Non-suplemented & -3.9615 & 1.1660 & 0.94 \\
\hline Supplemented & -3.6710 & 1.0390 & 0.85 \\
\hline \multirow[t]{2}{*}{ Joint } & -3.6844 & 1.0482 & 0.83 \\
\hline & \multicolumn{2}{|c|}{ K } & \\
\hline Non-suplemented & -2.7148 & 0.9426 & 0.97 \\
\hline Supplemented & -2.8207 & 0.9910 & 0.98 \\
\hline \multirow[t]{2}{*}{ Joint } & -2.7965 & 0.9795 & 0.97 \\
\hline & \multicolumn{2}{|c|}{$\mathrm{Na}$} & \\
\hline Non-suplemented & -2.5173 & 0.8595 & 0.99 \\
\hline Supplemented & -2.6569 & 0.9225 & 0.97 \\
\hline Joint & -2.6335 & 0.9112 & 0.97 \\
\hline
\end{tabular}

$\mathrm{r}^{2}$ - coefficient of determination.
Thus, the behavior observed in the present study may be explained by the fact that bone tissue presents the greatest mineral contents and adipose tissue does not present significant amount of the minerals (Silva, 1995).

Net requirements of Ca (13.02 g/kg EBW) estimated for a 400-kg BW animal, were higher than the ones observed by Silva et al. (2002b) and given by BR-CORTE (Valadares Filho et al., 2010) for Zebu animals in Brazil. In addition, the value in the present study was smaller than the one recommended by AFRC (1991) for a 400-kg LW animal (11.90 g/kg EBW).

Regarding $P$, net requirements were within the range from $7.91 \mathrm{~g} / \mathrm{kg}$ EBW (250-kg LW) and $6.70 \mathrm{~g} / \mathrm{kg}$-EBW (400-kg LW). AFRC (1991) and NRC (2000) recommended, for animals with $400 \mathrm{~kg}$ of LW and gain of $1.0 \mathrm{~kg} /$ day and adult weight of $450 \mathrm{~kg}$, P net requirements of 5.96 and $8.00 \mathrm{~g}$, respectively, which were close to the ones found in this study. In Brazilian conditions, P net requirements estimated by Silva et al. (2002b, c) and by BR-CORTE (Valadares Filho et al., 2010) were close to the ones estimated in this study.

When net requirements of $\mathrm{Ca}$ and $\mathrm{P}$ estimated in the present study are used, as well as the protein net requirement obtained by Moraes et al. (2010), for a 400-kg LW animal, we have the relationships $9.18 \mathrm{~g} \mathrm{Ca} / 100 \mathrm{~g} \mathrm{CP}$ retained and

Table 5 - Content estimate (g/kg EBW) and net requirement (g/kg EBWG) of Ca, P, Mg, K and $\mathrm{Na}$ in EBW of grazing Zebu cattle, in function of body weight

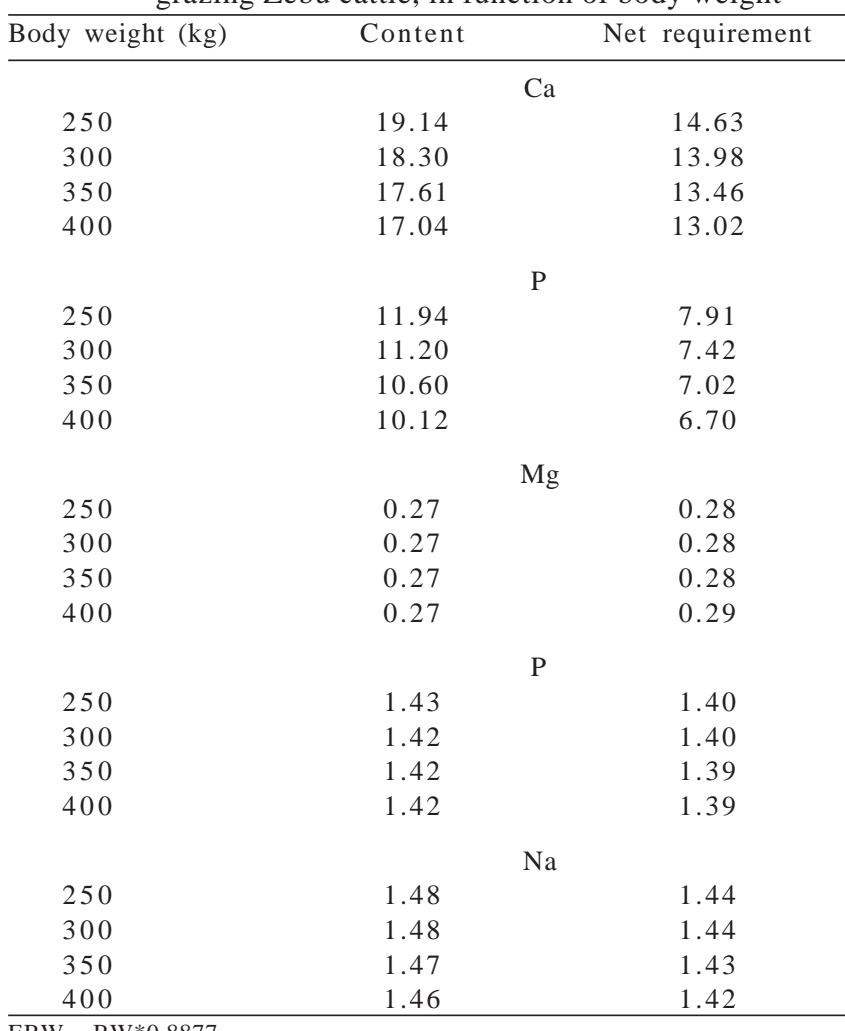

$\mathrm{EBW}=\mathrm{BW}^{*} 0.8877$ 
$4.72 \mathrm{~g} \mathrm{P} / 100$ g CP retained, which are higher than those obtained by NRC (2000), $7.10 \mathrm{~g} \mathrm{Ca} / 100 \mathrm{~g} \mathrm{CP}$ retained and

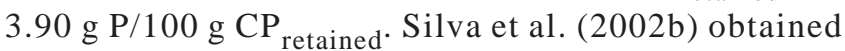
$6.44 \mathrm{~g} \mathrm{Ca} / 100 \mathrm{~g} \mathrm{CP}_{\text {retained }}$ and $4.78 \mathrm{~g} \mathrm{~Pa} / 100 \mathrm{~g} \mathrm{CP}$ retained. For the same $400 \mathrm{~kg}$ and by using net requirements of protein, and Ca and P obtained by BR-CORTE (Valadares Filho et al., 2010) for Zebu animals in Brazilian conditions, we obtain the relationships $9.25 \mathrm{~g} \mathrm{Ca} / 100 \mathrm{~g} \mathrm{CP}$ retained and $4.89 \mathrm{~g} \mathrm{P} / 100 \mathrm{~g}$ $\mathrm{CP}_{\text {retained }}$, which are close to the ones in this study.

In this research, net requirements of $\mathrm{Mg}$ for a $400-\mathrm{kg}$ BW animal were close to the ones estimated by Silva et al. (2002c) and by BR-CORTE (Valadares Filho et al., 2010). On the other hand, net requirement of $\mathrm{Mg}$ were much lower than the constant value of $0.45 \mathrm{~g} / \mathrm{kg}$ recommended by ARC (1980).

For grazing bovines, according to BR-CORTE (Valadares Filho et al., 2010),a 400-kg BW animal with $1.0 \mathrm{~kg}$ /day gain presents K net requirements of 2.54, which is lower than the ones estimated in this research.

Dietary requirement of Ca for $1.0 \mathrm{~kg}$ of gain of a $400-\mathrm{kg}$ BW animal, found in this study (Table 6), were close to the value $21.49 \mathrm{~g} / \mathrm{kg}$ BWG estimated by Silva et al. (2002b).

The total dietary requirements increased with increasing animal BW, by participating the maintenance requirements, which depend on the weight of the animals (Table 7). It was observed that total dietary requirement of the studied mineral

Table 6 - Dietary requirements for weight gain of Ca, P, Mg, K and Na of grazing Zebu bovines

\begin{tabular}{|c|c|c|c|c|c|}
\hline \multirow[t]{2}{*}{ Body weight $(\mathrm{kg})$} & \multicolumn{5}{|c|}{ Dietary requirement for gain (g/kg GPV) } \\
\hline & $\mathrm{Ca}$ & $P$ & $\mathrm{Mg}$ & K & $\mathrm{Na}$ \\
\hline 250 & 25.95 & 10.24 & 0.89 & 1.26 & 1.30 \\
\hline 300 & 24.80 & 9.61 & 0.88 & 1.26 & 1.28 \\
\hline 350 & 23.87 & 9.10 & 0.87 & 1.25 & 1.26 \\
\hline 400 & 23.09 & 8.68 & 0.87 & 1.25 & 1.25 \\
\hline
\end{tabular}

macro elements were close to the values recommended by BR-Corte (Valadares Filho et al., 2010) for grazing Nellore.

Contrary, Miranda et al. (2006) estimated total dietary requirements of Nellore animals selected for weight at yearling greater than the ones in the present study. However, according to the authors, the high values of total dietary requirements found were obtained with animals finished in confinement, so, extrapolation of those values for ration formulation for pasture finished animals should be seen carefully.

According to AFRC (1991), total dietary requirements of Ca and $\mathrm{P}$ for a $400-\mathrm{kg}$ BW animal with a $1.0-\mathrm{kg}$ daily gain would be 28.0 and $25.0 \mathrm{~g}$ /day, respectively. It is observed that for Ca, dietary requirements found in this study were the greatest and for $\mathrm{P}$, they were lower than the ones recommended by this board. For the same animal at matter, NRC (2000) estimates dietary requirement of 31.0 and $18.0 \mathrm{~g} /$ day for Ca and P, respectively. The value estimated in this study for Ca was lower than the one from NRC (2000), but the value obtained for $\mathrm{P}$ was close to it.

According to ARC (1980), for a 400-kg BW bovine with a $1.0-\mathrm{kg} /$ day of gain, the total dietary requirements of $\mathrm{Mg}$, $\mathrm{K}$ and Na would be 9.50; 43.38 and 4.64 g/day, respectively. Except for Mg requirement, which was lower, the total dietary requirements of $\mathrm{K}$ and Na were very close to the ones recommended by ARC (1980). According to Miranda et al. (2006), those differences are mainly because of the estimates of net requirements for weight gain.

For a 400-kg BW animal gaining $1 \mathrm{~kg}$ of LW/day and consuming $2.4 \%$ of LW of DM would have total dietary requirements of $0.32 ; 0.19 ; 0.10 ; 0.60$ and $0.07 \%$ in total dietary DM percentage of $\mathrm{Ca}, \mathrm{P}, \mathrm{Mg}, \mathrm{K}$ and $\mathrm{Na}$, respectively (NRC, 2000). It was observed that the values found here were higher for $\mathrm{Ca}$, practically equal for $\mathrm{P}, \mathrm{Mg}$ and $\mathrm{Na}$ and lower for $\mathrm{K}$ in comparison with the ones recommended by NRC(2000).

Table 7 - Total dietary requirements (maintenance $+1 \mathrm{~kg}$ of LW gain) of Ca, P, Mg, K and Na for an intake of $2.20 \%$ of body weight ${ }^{1}$ (BW - kg) of grazing Zebu bovine

\begin{tabular}{|c|c|c|c|c|c|c|c|c|c|c|}
\hline \multirow[t]{2}{*}{ BW (kg) } & \multicolumn{2}{|c|}{$\mathrm{Ca}$} & \multicolumn{2}{|c|}{$\mathrm{P}$} & \multicolumn{2}{|c|}{ Mg } & \multicolumn{2}{|c|}{ K } & \multicolumn{2}{|c|}{$\mathrm{Na}$} \\
\hline & g/day & \% DM & g/day & \% DM & g/day & $\%$ DM & g/ day & \% DM & g/day & $\%$ DM \\
\hline 250 & 33.65 & 0.61 & 16.13 & 0.29 & 5.30 & 0.10 & 27.79 & 0.51 & 3.17 & 0.06 \\
\hline 300 & 34.04 & 0.52 & 16.66 & 0.25 & 6.17 & 0.09 & 32.87 & 0.50 & 3.52 & 0.05 \\
\hline 350 & 34.65 & 0.45 & 17.33 & 0.23 & 7.05 & 0.09 & 37.95 & 0.49 & 3.88 & 0.05 \\
\hline 400 & 35.41 & 0.40 & 18.09 & 0.21 & 7.92 & 0.09 & 43.03 & 0.49 & 4.23 & 0.05 \\
\hline
\end{tabular}

$\mathrm{EBW}=\mathrm{BW} * 0.8877 ; \mathrm{BW}=$ Body weight.

${ }^{1}$ Average DM intake in this study. 


\section{Conclusions}

Total dietary macro mineral requirements increase according to body weight of the animals. The NRC system overestimates total dietary requirements of calcium and the calcium and phosphorus per $100 \mathrm{~g}$ of crude protein retained ratio. Total dietary requirements of mineral macro elements studied and the phosphorus per 100 g of crude protein retained ratios are close to the recommendations of BR-Corte (2010).

\section{References}

AGRICULTURAL AND FOOD RESEARCH COUNCIL - AFRC. A reappraisal of the calcium and phosphorus requirements of sheep and cattle. 6.ed. Nutrition Abstract and Reviews (Series B). Wallingford: 1991. p.573-612.

AGRICULTURAL RESEARCH COUNCIL - ARC. The nutrient requirements of ruminants livestock. London: 1980. 351 p.

BURNS, J.C.; POND, K.R.; FISHER, D.S. Measurement of forage intake. In: FAHEY JUNIOR, G.C. (Eds.) Forage quality, evaluation and utilization. Madison: America Society of Agronomy, 1994. p.494-531.

FONTES, C.A.A.; OLIVEIRA, R.C.; ERBESDOBLER, E.D. et al. Conteúdo de energia líquida para mantença e ganho do capim elefante e mudanças na composição corporal de novilhos em pastejo, durante a estação chuvosa. Revista Brasileira de Zootecnia, v.34, n.5, p.1711-1720, 2005.

FREGADOLLI, F.L. Composição corporal e exigências nutricionais de novilhos de três grupos genéticos em pastejo. 2005. 85f. Tese (Doutorado em Zootecnia) -Universidade Estadual Paulista, Faculdade de Ciências Agrárias e Veterinárias, Jaboticabal.

MIRANDA, E.N; QUEIROZ, A.C.; LANA, R.P. et al. Composição corporal e exigências nutricionais de macrominerais de bovinos Caracu selecionados e Nelore selecionados ou não para peso ao sobreano. Revista Brasileira de Zootecnia, v.35, n.3, p.1201-1211, 2006.

MERTENS, D.R. Gravimetric determination of amylase treated neutral detergent fiber in feeds with refluxing in beakers or crucibles: collaborative study. Journal of AOAC International, v.85, n.6, p.1212-1240, 2002.
MORAES, E.H.B.K.; PAULINO, M.F.; MORAES, K.A.K. et al. Exigências de proteína de bovinos anelorados em pastejo. Revista Brasileira de Zootecnia, v.39, n.3, p.601-607, 2010.

MORAES, S.S. Principais deficiências de minerais em bovinos de corte. Campo Grande: EMBRAPA Gado de Corte, 2001. 27p. (Documentos, 112).

NATIONAL RESEARCH COUNCIL - NRC. Nutrient requirements of beef cattle. 7. rev. ed. National Academy Press, Washington, D.C.: 2000. 242p.

PAULINO, P.V.R.; COSTA, M.A.; VALADARES FILHO, S.C. et al. Exigências nutricionais de zebuínos: minerais. Revista Brasileira de Zootecnia, v.33, n.3, p.770-780, 2004.

REGAZZI, J.A. Teste para verificar a identidade de modelos de regressão. Pesquisa Agropecuária Brasileira, v.31, n.1, p.1-17, 1996.

ROBELIN, J. Growth of adipose tissues in cattle: partitioning between depots, chemical composition and cellularity, a review. Livestock Production Science, v.14, p.349-364, 1986.

SILVA, J.F.C. Exigências de macro elementos inorgânicos para bovinos: o sistema ARC/AFRC e a experiência no Brasil. In: SIMPÓSIO INTERNACIONAL SOBRE EXIGÊNCIAS NUTRICIONAIS DE RUMINANTES, 1995, Viçosa, MG. Anais... Viçosa, MG: Universidade Federal de Viçosa, 1995. p.467-504.

SILVA, D.J.; QUEIROZ, A.C. Análise de alimentos: métodos químicos e biológicos. 3.ed. Viçosa, MG: UFV, Imprensa Universitária, 2002. 165p.

SILVA, F.F.; VALADARES FILHO, S.C.; ÍTAVO, L.C.V. et al. Composição corporal e requisitos energéticos e protéicos de bovinos nelore, não-castrados, alimentados com rações contento diferentes níveis de concentrado e proteína. Revista Brasileira de Zootecnia, v.31, n.1, p.503-513, 2002a.

SILVA, F.F.; VALADARES FILHO, S.C.; ÍTAVO, L.C.V. et al. Composição corporal e requisitos líquidos e dietéticos de macro elementos minerais de bovinos nelore não-castrados. Revista Brasileira de Zootecnia, v.31, n.2, p.757-764, 2002b.

SILVA, F.F.; VALADARES FILHO, S.C.; ÍTAVO, L.C.V. et al. Exigências líquidas e dietéticas de energia, proteína e macro elementos minerais de bovinos de corte no Brasil. Revista Brasileira de Zootecnia, v.31, n.2, p.776-792, 2002c.

TOKARNIA, C.H.; DÖBEREINER, J.; PEIXOTO, P.V. Deficiências minerais em animais de fazenda, principalmente bovinos em regime de campo. Pesquisa Veterinária Brasileira, v.20, n.3, p.127-138, 2000.

VALADARES FILHO, S.C.; MARCONDES, M.I.; CHIZZOTTI, M.L. et al. Exigências nutricionais de zebuínos puros e cruzados: BR-CORTE. 2.ed. Viçosa, MG, 2010. 193p.

Van SOEST, P.J.; ROBERTSON, J.B. Analysis of forages and fibrous foods. Ithaca: Cornell University, 1985. 202p. 